\title{
Experimental Study on Mold-Lay Filament instead of Wax in Investment Casting Process
}

\author{
Imam Kusyairia, Helmy Mukti Himawan ${ }^{b}$, Moch Agus Choiron $^{c}$, Yudy Surya Irawan ${ }^{\text {, }}$, Rachmat Safari \\ Dagus Resmana Djuandac \\ a,b Politeknik Kota Malang \\ JI Tlogowaru No 3, Kedungkandang, Malang Telephone/fax (0341) 754088 \\ c,d Universitas Brawijaya \\ JI. Veteran Malang, Ketawanggede, Kecamatan Lowokwaru, Kota Malang, Jawa Timur 65145 \\ e,f Balai Besar Logam dan Mesin \\ Jl. Sangkuriang No.12, Dago, Kecamatan Coblong, Kota Bandung, Jawa Barat 40135 \\ e-mail: kusyairi1408@gmail.com
}

\begin{abstract}
Metal casting with investment casting method is metal casting which has the ability to produce accurate parts and has a controlled fineness. Current technological developments are very influential in the development of investment casting. One of them has been found mold-lay filament as a substitute for wax, which is now wax is one of the main components in investment casting process. Mold-lay filament is printed using a 3D Printer machine. In this study, the wax in the investment casting process was replaced by a mold-lay filament with the specifications $0.75 \mathrm{~kg} / 0.55 \mathrm{lb}$ of $1.75 \mathrm{~mm}$ MOLDLAY filament, prints at temperatures of $170-180^{\circ} \mathrm{C}$. The result show that mold-lay flutes are also able to come out well from slurry molds, but require more time than wax, this is because one of the plastic mold-lay compositions, which takes a long time for the moldlay fillment to come out of the mold. Further research suggestions are needed further testing in terms of roughness of the product with moldlay filament and compared with wax. This will also see if there are any remaining moldlay filaments from the mold.
\end{abstract}

Keywords: moldlay; investment casting; wax

\section{INTRODUCTION}

Metal casting is one of the most important technologies for manufacturing complex parts. Investment casting or knonw as lost wax casting is casting method which has ability to produce complex parts with excellent surface finish and high accuracy on complex shapes [1][2]. This phenomena makes investment casting to be difficult to be analyzed and modelled [3]. Investment casting or known as precision casting are widely used in automotive industry, aerospace industry, machine building, chemicals and even medicine industry [4]. With the advantages possessed by investment casting, many researchers carried out a variety of studies such as numerical simulations of the wax injection process [5][6], wax material compositon with other other elements, especially in the vacuum casting process on the surface quality of the cast metal [7], camphor and needle coke to enhance the porosity of ceramic shell [8], the effect of variations of wax burning time on product accuracy [9] and numerical simulation of transient heat transfer using phase change material (pcm) with COMSOL multi-physics software [10].

In investment casting, it is need to be careful in formulating wax to ensure dimensional stability and no contraction during heat variations and cooling steps in mold preparation [11][12]. In its development, the use of 3D printing [13] for making molds in investment casting has begun to be utilized, such as the use of machines based on the process of stereolithography (SLA) [14]. The 3D printing machines are devices that are simple, flexible and have a cost effective approach to produce a physical model of a component [15]. Filaments that are commonly used in 3D printing made from polymers include polylactic 
acid (PLA), acrylonitrile butadiene styrene (ABS), polyethylene terephthalate (PET), thermoplastic polyurethane (TPU), high impact polystyrene (HIPS), polyvinyl alcohol (PVA), and nylon [16][17][18]. The ability of PLA to produce components with high accuracy has been investigated in the fabrication of micro needle arrays [19]. Currently developing filament that serves as a substitute for wax on investment casting, namely mold-lay filament. Mold-lay is an ideal material for permanent casting and investment casting. With a printing temperature of $170-180^{\circ} \mathrm{C}$, similar to the conditions used to print with PLA. The main difference between mold-lay and other plastics is the transition of the material into a liquid with very low viscosity when heated to $270^{\circ} \mathrm{C}$. This allows it to flow easily from the mold cavity [20]. In this research mold-lay will be used to replace wax in investment casting and to test the ability of mold-lay fillament in the slurry coating process and mold-lay filament ability in the dewaxing process.

\section{Methods}

The study focus on mold-lay filament as subtituted of wax in investment casting. MoldLay fillament is a filament that functions like wax, which is structurally unchanged, is also able to maintain its shape at room temperature and will melt as wax when heated to $270^{\circ} \mathrm{C}$. This research method is taken in several steps, namely design, printing with a 3D Printer, making a gate system, making slurry

\subsection{Design}

In this study, the design of origami crash box use 3 types of design, namely 3 segments, 5 segments and 6 segments. The design of the object has a machine length of $114.5 \mathrm{~mm}$, a width of $68.5 \mathrm{~mm}$ and a height of $126 \mathrm{~mm}$ with a thickness of $3 \mathrm{~mm}$ [21][22]. This design has several difficulties in the process of making gates and the slurry coating process, due to the complex and sharp angular shape in each segment. The design of the origami pattern crash box can be seen in Figure 1.

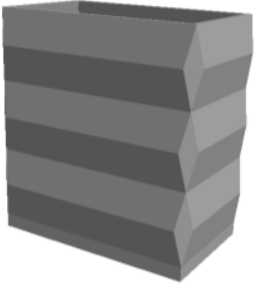

a) 3 segmen

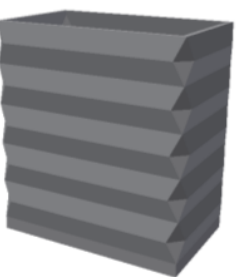

b) 5 segmen

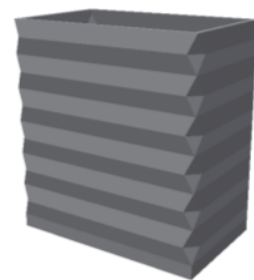

c) 6 segmen

Figure 1. Crash box origami pattern

\subsection{D Printing Process}

The next step after completing the 3D design process is to convert the cad file into .st form, and opened by flash print software. Printing settings on the 3D printer machine with a layer height of $0.1 \mathrm{~mm}, 100 \%$ fill density, print speed of $40 \mathrm{~mm} / \mathrm{s}$, extruder temperature of $120^{\circ} \mathrm{C}$ and bed temperature of less than $30^{\circ} \mathrm{C}$. The filament specifications are with a diameter of $1.75 \mathrm{~mm}$. 3D printer settings and processing process can be seen in Figure 2, the average time needed in the process of processing around 29 hours per design and requires 61.9 meters of material per design, details of this data can be seen in Table 1.
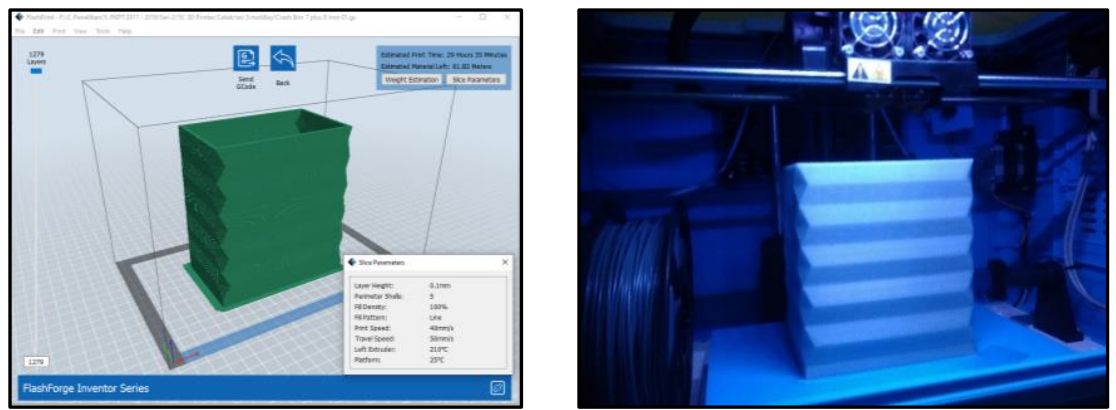

Figure 2. Software flash print and printing process 
JEMMME (Journal of Energy, Mechanical, Material, and Manufacturing Engineering) Vol.5, No. 1, May 2020 | doi: 10.22219 /jemmme.v5i1.10602

Table 1. Time and needed material

\begin{tabular}{llll}
\hline Type & Origami pattern & Time & Material \\
\hline First & 3 segments & $30 \mathrm{~h} 18 \mathrm{~m}$ & 63,03 meters \\
Second & 5 segments & $29 \mathrm{~h} 35 \mathrm{~m}$ & 61,82 meters \\
Third & 7 segments & $29 \mathrm{~h} 9 \mathrm{~m}$ & 60,90 meters \\
\hline
\end{tabular}

The results of the 3D printer products are ilustrated in Figure 3. Each design is printed twice, and has taken 174 hours and 371.5 meters. The evaluation of printing $3 \mathrm{~d}$ printer with mold-lay filament is a print bed below $30^{\circ} \mathrm{C}$, if given a temperature of $30^{\circ} \mathrm{C}$, the filament attached to the bed will be curved, this can be seen in the print of a 3-segment origami pattern crash box. This is because the filament that attaches to the bed is continuously exposed to heat, and makes the filament warped, to overcome this problem, giving a bed temperature of $20-25^{\circ} \mathrm{C}$ in a printing process that takes a long time.

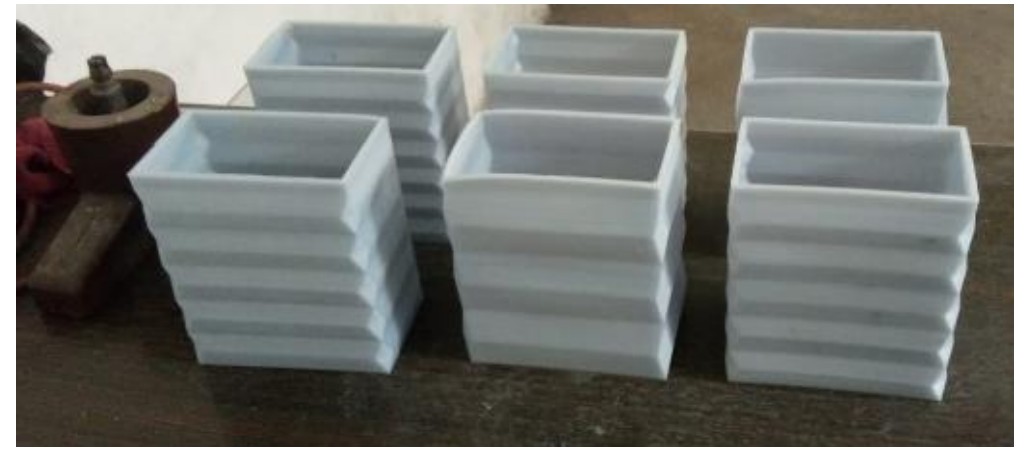

Figure 3. The result of $3 D$ printer

\subsection{Making Gate System}

The design of the gate of metal into the mold is a challenge because origami-shape that have many angles, and a thickness of $3 \mathrm{~mm}$. What is done in this process is designing channels, making runners and making channels. Runner function is to determine the model of the entry of metal liquid when pouring, to go to the angle of the object. The shape of the runner can be seen in Figure 4a. Figure 4 is the process of assembling runners with objects. The assembly process is carried out with the help of a soldering equipment, so that the model with the runner can be fused.

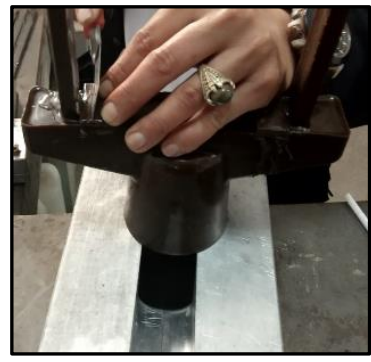

a) runner model

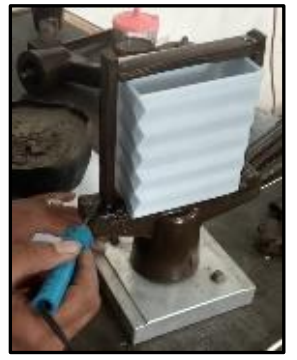

b) assembly

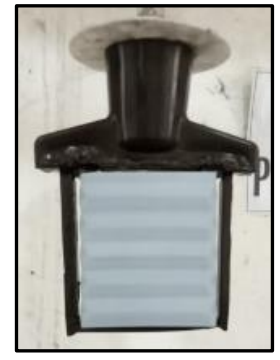

c) runner system

Figure 4. Assembly process with runner

\subsection{Making slurry}

The composition of making slurry is zircon flour and colloidal silica, with the addition of wetting agent and deep foarmer. The common ratio used in making slurry is zircon flour as much as $4 \mathrm{~kg}$, colloidal silica $1 \mathrm{~L}$ with added wetting agent and deep foamer each of 5 drops. Function of the wetting agent as a slurry binder and deep foarmer as a slurry hardener. Making slurry requires checking the liquidity of the slurry liquid, when the slurry is too runny, the slurry cannot stick to the model. The liquidity checking process with a baumeter equipment, but in this checking process, the researchers used a tube-shaped object with a volume of $50 \mathrm{ml}$ and was given a hole at the bottom. Slurry can be said to meet the standard when slurry runs out within $15 \mathrm{~s}$. 


\section{Result AND Discussion}

\subsection{The Ability of Fillament on Slurry Coating Process}

Slurry coating testing has several stages, namely slurry coating, zircon sand coating, mullite coating. The first coating test is a slurry coating with the target coating on the outside and inside, able to stick to the model. The next layer after the slurry is perfectly attached, the coating is followed by the zircon sand coating. The zircon sand coating functions as a refiner of the model pattern, the zircon sand coating process can be done twice. Furthermore, slurry coating and fine mullite twice, medium mullite 3 times and coarse mullite 3 times. Slurry coating is carried out at each step of the coating, for example slurry coating, fine mullite coating, slurry coating, fine mullite coating, slurry coating, moderate mullite coating, and so on.

In each coating process is left to stand for 3 hours, this serves so that the material covering the model is perfectly attached. After the coating process is complete, the next step is the process of planting the model for 24 hours. The process of coating the slurry is not only on the outside, but the inside is also perfectly coated with the slurry. The process of beginning to the end coating can be seen in Figure 5. In this study, it can be concluded that the mold-lay filament can be coated with slurry according to the wax function in the investment casting process. After the mold-lay filament is coated with slurry, it is referred to as a mold.

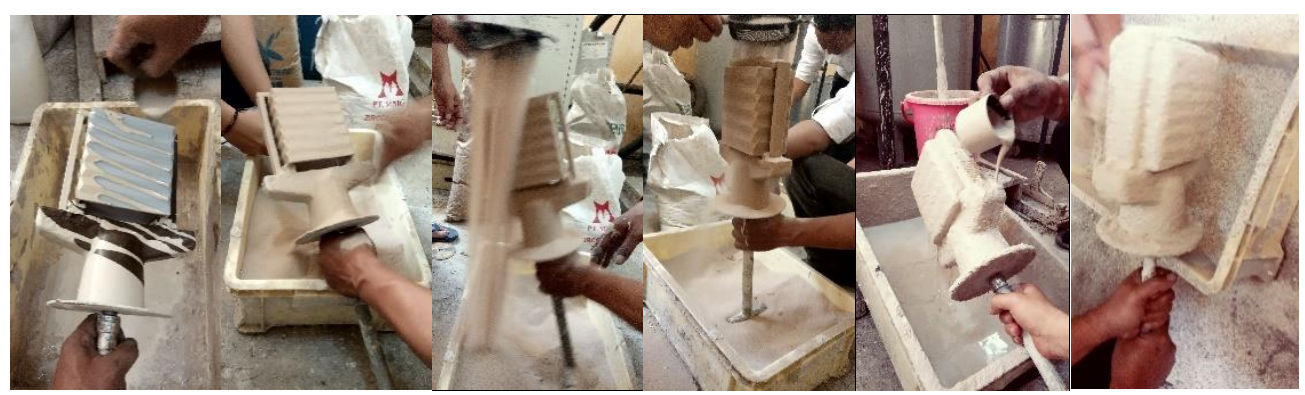

Figure 5. Slurry coating

\subsection{The Ability of Fillament on Slurry Coating Process}

The next test is testing the ability of the moldl-ay filament in the dewaxing process. Dewaxing is the process of removing wax from a mold by heating it to a certain temperature. This test is needed, to know the ability of the mold-lay filament to melt properly. When the filament is not able to melt completely, it will cause defects in casting during the pouring process. This testing process by heating the mold with a bunner, the burner is designed like a blower with a long handle, this is to facilitate the reach of each side of the mold, as shown in Figure 6.

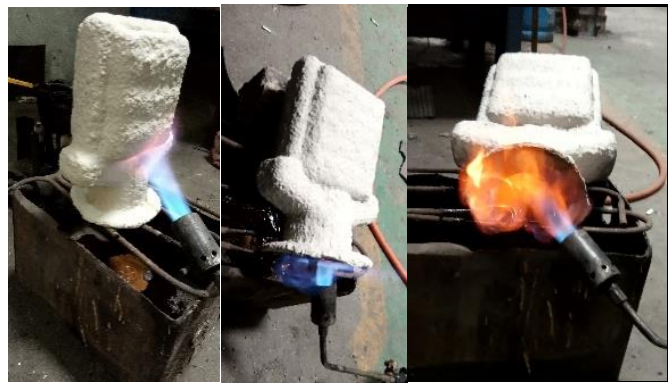

Figure 6. Dewaxing process

The results of this study can be said that the mold-lay filament is able to come out of the mold, but with a longer time than wax around 10 minutes, this is because one of the compositions of the moldlay filament is plastic and requires a higher temperature than the wax to melt the mold-lay filament, due to the liquid temperature of the mold-lay filament 
$270{ }^{\circ} \mathrm{C}$, while the wax material has a flash point temperature of $200-240^{\circ} \mathrm{C}$. The results of the dewaxing process can be seen in Figure 7, it appears that the mold is able to form a perfect pattern of objects, and the mold-lay filament is able to come out of the mold. In further research is needed study on the pouring process, this is to see if there is any residual from the mold-lay filament from the mold.

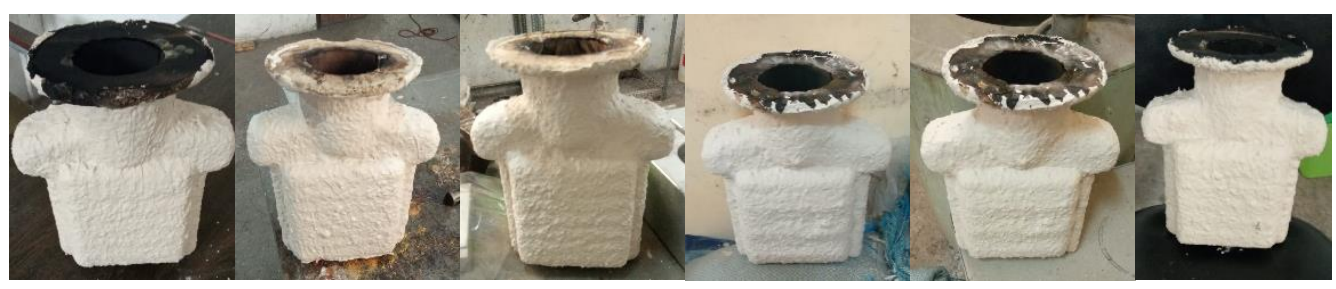

Figure 7. The result of dewaxing process

\section{Conclusions}

1. Mold-lay Fillament able to be coated by slurry, zircon sand and mullite completely, it can be seen from the coating that is able to stick well.

2. The mold-lay fillament is able to come out well from the slurry mold, but requires more time than wax, this is because the mold-lay composition is plastic, which takes a long time for the mold-lay fillment to come out of the mold.

3. Further research requires the testing in terms of roughness of the product with moldlay filament and compared with wax. This will also see if there are any remaining moldlay filaments from the mold.

\section{ACKNOWLEDGMENT}

Thank you to the Ministry of Research, Technology and Higher Education, Directorate General of Research and Community Service Strengthening and Research Services that has funded all research, Announcement T / 140 / E3 / RA.00 / 2019 Dated February 25th, 2019.

\section{REFERENCES}

1. Annu, J., Umamaheswari, B. \& Lakshmi, C.S., "Comparative evaluation of marginal accuracy of metal copings fabricated using direct metal laser sintering, computer-aided milling, ringless casting, and traditional casting techniques: An In vitro study", Contemporary Clinical Dentistry, 2018; Vol. 9(3):421-426.

2. Investment casting sand and flour conveyed from bulk bags automatically, dust-free. Modern Casting [Internet]. 2019 Sep;40-2. Available from: https://www.moderncasting.com/articles/2019/09/10/investment-casting-sand-andflour-conveyed-bulk-bags-automatically-dust-free

3. Luca, A. et al., "Research to Improve the Surface Quality of Metal Parts Made by Investment Casting", Academic Journal of Manufacturing Engineering, 11(2), pp. 7479 . http://search.ebscohost.com/login.aspx?direct=true\&db=egs\&AN=88315022\&site=eh ost-live (Accessed: 9 December 2019).

4. Rahimian, M. et al., "Physical Simulation of Investment Casting of Complex Shape Parts", Metallurgical \& Materials Transactions. Part A, 2015; 46(5):2227-2237. https://doi.org/10.1007/s11661-015-2815-6.

5. Wang, D. et al., "Numerical Simulation of the Wax Injection Process for Investment Casting", Materials \& Manufacturing Processes, 2013; Vol. 28(2):220-224. https://doi.org/10.1080/10426914.2012.746788.

6. Ambrosi, D. \& Preziosi, L., "Modeling Injection Molding Processes with Deformable Porous Preforms", SIAM Journal on Applied Mathematics, 2000; Vol. 61(1):22-42.

7. Roach, P. and Ponton, C., "Aqueous electrophoretic deposition as a method for producing an investment casting shell mould ceramic face-coat. Part 1: formation of a 
carbon-filled investment casting wax electrode material", Journal of Materials Science, 2013; Vol. 48(21):7476-7492. https://doi.org/10.1007/s10853-013-7562-8.

8. Khyati Tamta and Karunakar, D. B., "Enhancement of Porosity of the Ceramic Shell in Investment Casting Process Using Needle Coke and Camphor", Applied Mechanics \& Materials, 2014 ;

https://doi.org/10.4028/www.scientific.net/AMM.592-594.269

(592-594):269-275.

9. Shah, S.A., Naqash, T.A., Padmanabhan, T.V., Subramanium, Lambodaran \& Nazir, S., "Influence of Time of Placement of Investments for Burnout and the Type of Rings Being Used on the Casting Accuracy", Journal of Indian Prosthodontic Society, 2014; Vol. 14(1):67-71. https://doi.org/10.1007/s13191-013-0264-8

10. Songhao Wang and Millogo, J. D., "Phase Changing Material Used with RP Technology in Quick Wax Molding for Investment Casting", Computer-Aided Design \& Applications, 2012; Vol. 9(3): 409-418. doi: 10.3722/cadaps.2012.409-418.

11. Bandyopadhyay-ghosh, S., Reaney, I.M., Johnson, A., Hurrell-gillingham, K., Brook, I.M. \& Hatton, P.V., "The effect of investment materials on the surface of cast fluorcanasite glasses and glass-ceramics", Journal of Materials Science: Materials in Medicine, 2008; Vol. 19(2):839-46. https://doi.org/10.1007/s10856-007-3207-2

12. Rajagopal, P., Chitre, V. \& Aras, M., "A comparison of the accuracy of patterns processed from an inlay casting wax, an auto-polymerized resin and a light-cured resin pattern material: Official Publication of Indian Society for Dental Research Official Publication of Indian Society for Dental Research", Indian Journal of Dental Research, 2012; Vol. 23(2):152-6. https://doi.org/10.4103/0970-9290.100418.

13. Wetzel, S., "Printing Possibilities", Modern Casting, 2013; 103(12):28-33. Available at: https://www.qgdigitalpublishing.com/publication/?m=55001\&i=628953\&p=30\&ver=ht $\mathrm{ml} 5$.

14. Stereolithography Process Leads to Savings for Investment Caster. Modern Casting, 2017; 107(10), pp. 48-49. Available at: https://www.qgdigitalpublishing.com/publication/?m=55001\&i=626804\&p=50.

15. Kuo, C.-C. et al., "Development of a flexible modeling base for additive manufacturing", International Journal of Advanced Manufacturing Technology, 2018; Vol. 94(14):1533-1541. https://doi.org/10.1007/s00170-017-1028-0.

16. Shin, J., Sandhu, R.S. \& Shih, G. 2017, "Imaging Properties of 3D Printed Materials: Multi-Energy CT of Filament Polymers", Journal of Digital Imaging, vol. 30(5):572-575. https://doi.org/10.1007/s10278-017-9954-9.

17. Chiulan, I., Frone, A.N., Brandabur, C. \& Panaitescu, D.M., "Recent Advances in 3D Printing of Aliphatic Polyesters", Bioengineering, 2018; Vol. 5(1). https://doi.org/10.3390/bioengineering5010002.

18. Yuan, H., Xing, K. \& Hung-Yao, H., "Trinity of Three-Dimensional (3D) Scaffold, Vibration, and 3D Printing on Cell Culture Application: A Systematic Review and Indicating Future Direction", Bioengineering, 2018; vol. 5(3). https://doi.org/10.3390/bioengineering5030057.

19. Krieger, K.J., Bertollo, N., Dangol, M., Sheridan, J.T., Lowery, M.M. \& Eoin, D.O., "Simple and customizable method for fabrication of high-aspect ratio microneedle molds using low-cost 3D printing", Microsystems \& Nanoengineering, 2019; Vol. 5(42):1-14. https://doi.org/10.1038/s41378-019-0088-8.

20. Lefebvre J. "Bringing Industrial Manufacturing to the Desktop with New MoldLay 3D Printing Filament". 3D Printing Industry. $\underline{2015}$.

21. Kusyairi, I., "The Influence of Origami and Rectangular Crash Box Variations on MPV Bumper with Offset Frontal Test Examination toward Deformability", JEMMME (Journal of Energy, Mechanical, Material and Manufacturing Engineering), 2017; Vol. 2(2):1-8. https://doi.org/10.22219/jemmme.v2i2.5070.

22. Kusyairi, Imam et al. "Effects of Origami Pattern Crash Box and Rectangular Pattern Crash Box on the Modelling Of MPV Car Structure on Deformation". JEMMME (Journal of Energy, Mechanical, Material, and Manufacturing Engineering), 2018; Vol. 3(2):6168. https://doi.org/10.22219/jemmme.v3i2.6831. 